\title{
SECTORAL ENERGY-CO2 EMISSIONS USING AN ENVIRONMENTAL INPUT-OUTPUT FRAMEWORK
}

\author{
Mukaramah Harun \\ Universiti Utara Malaysia, Malaysia \\ Siti Aznor Ahmad \\ Universiti Utara Malaysia, Malaysia \\ Noorasiah Sulaiman \\ Universiti Kebangsaan Malaysia, Malaysia \\ Djihad Tria* \\ Universiti Utara Malaysia, Malaysia
}

\begin{abstract}
Global climate change is an alarming problem nowadays. Weather temperatures have been uncertain because of what many scientists claim is the effect of greenhouse gases, contributed mainly by the energy industry. In Malaysia, the energy industry provides a significant contribution to it economy making up about 20 percent of the GDP. Malaysia is the third largest natural gas exporter in the Asia-Pacific region in 2011 and eleventh in the world (British Petroleum Statistical Review of World Energy, 2014). Malaysia's $\mathrm{CO}_{2}$ emission recorded at 185 million tonnes in 2010 (International Energy Agency, 2012). Mohd Safaai et al. (2011) projected that without any mitigation measures 285.73 million tonnes of $\mathrm{CO}_{2}$ will be released in 2020. In the Copenhagen forum 2009, Malaysia has pledged to reduce $40 \%$ of carbon emissions by 2020 compared to the 2005 levels. Motivated by the government efforts, this study will construct environmentally extended input-output framework for Malaysia to obtain the energy-related $\mathrm{CO}_{2}$ emission intensities by sectors. The study is responded to the inadequate of reliable data on Malaysia's sectoral $\mathrm{CO}_{2}$ emissions and to the growing awareness of the effectiveness of Malaysia climate change policies. This study expanding the current understanding of interactions among economic activities, energy intensities, and $\mathrm{CO}_{2}$ emissions. Results of this study found that Transportation recorded the second highest contributor to $\mathrm{CO} 2$ emission, and these findings were different to many other existing studies that found transportation sector as a main contributor to $\mathrm{CO}_{2}$ emission. In addition, results suggest that it is necessary to control environmental problems and encourage the energy use efficiency in the production process, particularly in the Building and construction sector, Transportation, Electricity, gas and water and Agriculture sector in Malaysia The findings will help the policy-makers particularly in Malaysia to develop a strategic plan and tools to manage $\mathrm{CO} 2$ emission with respect to climate change in these four sectors.
\end{abstract}

Keywords: Energy, Energy Intensities, $\mathrm{CO}_{2}$ Emission, Climate Change, Input-Output Analysis.

\footnotetext{
- Corresponding Author: School of Economics, Finance and Banking, Universiti Utara Malaysia, 06010 UUM Sintok, Kedah Darul Aman, Malaysia; Tel: +6 (11) 5856 2504; Email: triadjihad@ gmail.com
} 


\section{INTRODUCTION}

Malaysia has relatively very high $\mathrm{CO}_{2}$ emission as compared to other Southeast Asia nations, measures at 8.03 metric tonnes $\mathrm{CO}_{2}$ per capita and 0.31 tonnes per GDP compared to Philippine at 1.06 metric tonnes $\mathrm{CO}_{2}$ per capita and 0.15 tonnes per GDP, and Indonesia 1.81 metric tonnes $\mathrm{CO}_{2}$ per capita and 0.17 tonnes per GDP (World Bank, 2014). Malaysia registered a continuously significant growing $\mathrm{CO}_{2}$ emission throughout the period 1978-2016 as shown in Figure 1. Energy demand ${ }^{1}$ also shown a similar trend which reflects the burning of fossil fuels like coal, oil and natural gas and the use of gasoline such as Ron 95, Ron 97 and diesel contributed much to the $\mathrm{CO}_{2}$ emission. Despite the continue increased in $\mathrm{CO}_{2}$ emission and energy demand, Gross Domestic Product (GDP) is fluctuating through-out the period 1978 to 2016 as pictured in Figure 2. During the high economic growth period, the $\mathrm{CO}_{2}$ emission and energy demand grew significantly, while, during the economic recession, $\mathrm{CO}_{2}$ emission and energy demand fell, but only marginally (Malaysian Energy Information Hub, 2017; World Bank, 2018).

Figure 1: Energy demand and $\mathrm{CO}_{2}$ emission in Malaysia

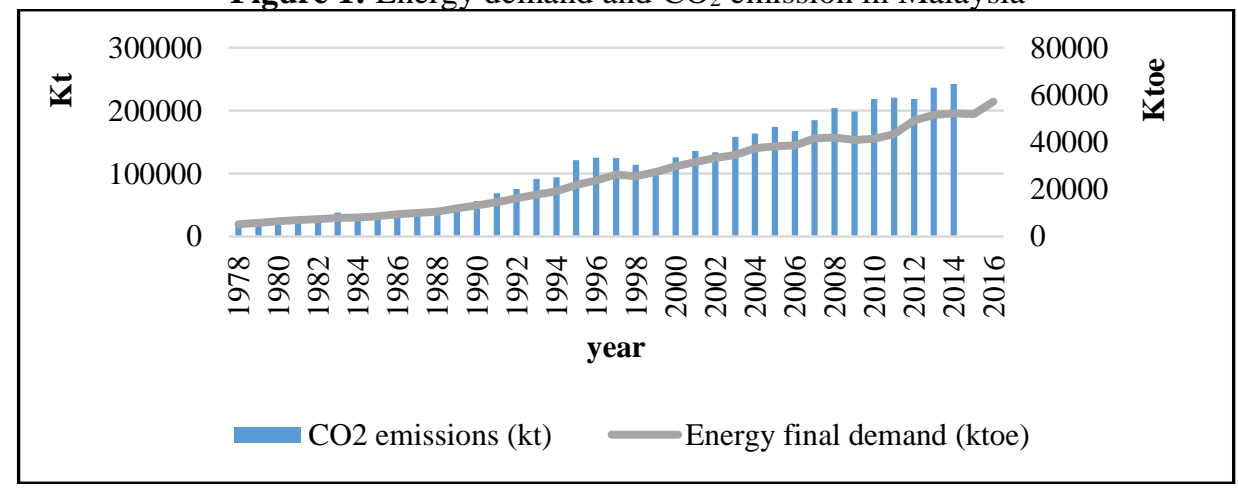

Source. Malaysia Energy Commission, 2017

Figure 2: Energy final demand and economic growth in Malaysia

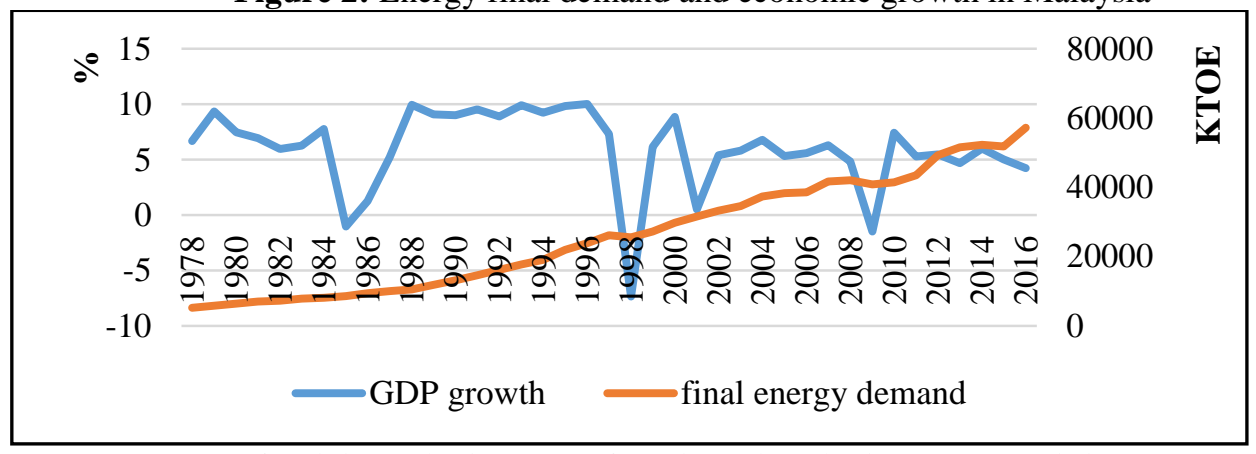

Source: Department of Statistics, Malaysia Energy Information Hub, Malaysia Energy Commission 2017, World Bank, 2018

\footnotetext{
${ }^{1}$ Demand of coal, oil and natural gas, gasoline, diesel etc.
} 
Figure 3 shows final energy demand by sector in 2016. The highest growth in energy demand is transportation sector with $42 \%$, followed by industrial sector $(28 \%)$, non-energy (15\%), residential and commercial (14\%), and agricultural sector (1\%). It corresponds with result from Ong et al. (2012) who suggested that transportation sector keep increasing due to the growth in household income and number of vehicles on road.

Figure 3: Final energy demand by sector in 2016 in Malaysia

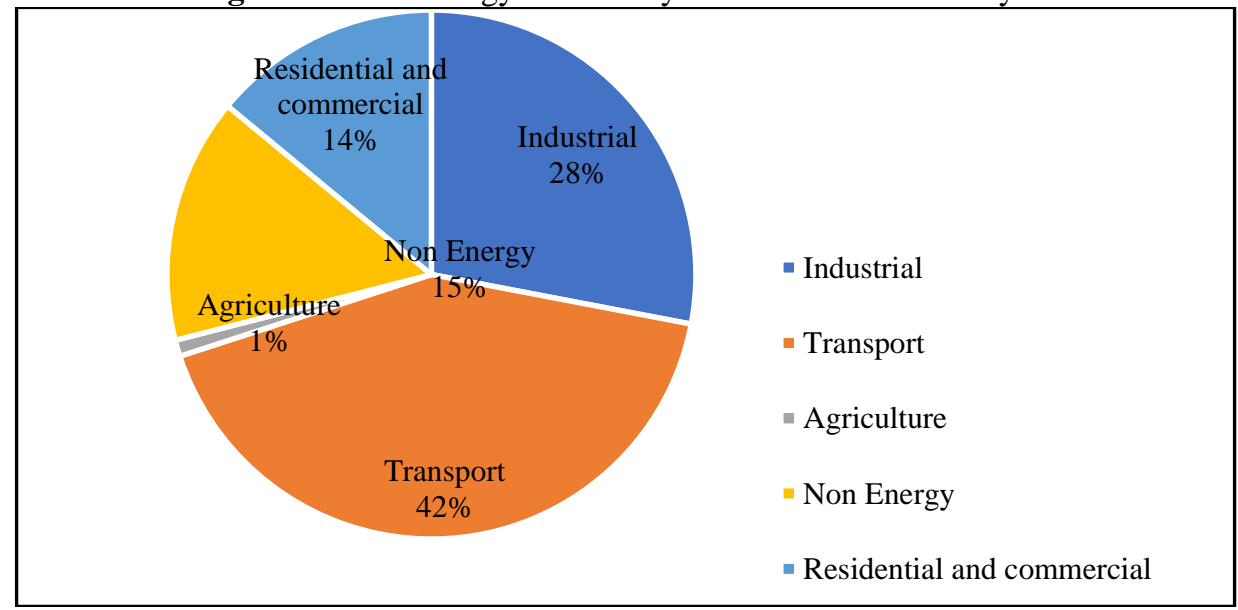

Source: Malaysia Energy Statistic, Malaysia Energy Commission, 2017

In light of significant increase in $\mathrm{CO}_{2}$ emission and the global climate change issues, Malaysia is attempting to reduce the amount of $\mathrm{CO}_{2}$ emission generated from its economic activities. The Prime Minister announced during COP15 in Copenhagen that the country would voluntarily reduce its carbon emissions intensity of GDP by the year 2020 by $40 \%$ compared to 2005 levels. Therefore, there is an urgent need for actions on $\mathrm{CO}_{2}$ emission in order to avert its worst impacts on climate change. Directed by this we interested to find an answer to the following questions: (1) how big $\mathrm{CO}_{2}$ emissions is produced by each sector? and (2) which sectors produce relatively higher $\mathrm{CO}_{2}$ emissions? Accordingly, the objective of this study is 1) To estimate the $\mathrm{CO}_{2}$ emission intensities of each sector, and (2) to identify sectors with relatively high $\mathrm{CO}_{2}$ emission intensity.

This study is employing an environment energy input-output framework which it can be used in environmental studies by linking economic and environmental variables, on the production and consumption interventions. Environmentally-extended input-output (EEIO) evaluates the linkages between economic consumption and allows the estimation of energy emission intensities of each sectors and can maps all the interactions between the sectors in the Malaysian economy. The framework reveals the channels through which the environmental burdens of production activities are transmitted throughout the economy.

This study contains five sections, and the first section focuses on the background and objective of the study. The second section reviews the literature. The third section explains the methodology and model of the study. Section four covers the analysis of the results and discussions of the study. The final section highlights the conclusion. 


\section{LITERATURE REVIEW}

There are several studies that have been investigated about energy consumption and $\mathrm{CO}_{2}$ emissions which using several approaches in developed and developing countries. Yildizhan (2018) investigated the energy consumption and $\mathrm{CO}_{2}$ emission in crop production and agriculture especially in strawberry production in Iran. He finds that total cumulative electric energy consumption for a ton of strawberry production is up to $6703.042 \mathrm{MJ}$ in open field and 4200.881 $\mathrm{MJ}$ in the greenhouse. With regards to $\mathrm{CO}_{2}$ emissions, to produce one ton of strawberry lead to production of $506.07 \mathrm{~kg}$ of $\mathrm{CO}_{2}$ (greenhouse) and $243.06 \mathrm{~kg}$ of $\mathrm{CO}_{2}$ (open field). Thus, higher energy consumption could lead to higher cumulative $\mathrm{CO}_{2}$ in greenhouse compared to open fields.

$\mathrm{Li}$, Ma, Zhang and Wen (2018) examined the energy demand and $\mathrm{CO}_{2}$ emissions related to industries in China. Based on demand and supply theory, they indicated five sectors in demanding energy and $\mathrm{CO}_{2}$ emission. The sectors are agriculture, industry and construction, transportation, service and residential living sectors. Agriculture demand consumption for coal as much as 55\% of total final energy, transportation demand consumption for fossil-based fuels such as gasoline, diesel and kerosene as high as $87 \%$ of total final energy and industry and construction sector demand consumption for coal, oil, natural gas and electricity and heat as $88 \%, 36 \%, 55 \%$ and $71 \%$ of total final energy respectively. They concluded that final energy demand in China will increase tremendously until the year 2030 in all sectors afore mentioned above. With regard to $\mathrm{CO}_{2}$ emission, they report that China should reduce $\mathrm{CO}_{2}$ emission in the future between $80 \%$ and $85 \%$ using primary sources such as coal for all sectors. They suggested that the development of carbon capture and storage (CCS) technology or other carbon-negative technologies are important to implement in China.

Jia et al. (2018) analysed $\mathrm{CO}_{2}$ emission by industries in Nanchang, China. By using index decomposition analysis, energy consumption in industries increased by $0.14 \mathrm{Mt}$ with growth rate of $1.72 \%$ in the first stages of period $1998-2000$, and then steadily increased by $7.42 \mathrm{Mt}$ at a rate of $89.34 \%$ in the second stage of period 2001-2005. In the third stage of period 2006-2010, this energy consumption increased again by $5.71 \mathrm{Mt}$ at a rate of $36.28 \%$ and grew by $3.35 \mathrm{Mt}$ at a rate of $15.60 \%$ in (2011-2015), with a total growth rate of $203.42 \%$. However, the $\mathrm{CO}_{2}$ emission is dropped to $-9.42 \%$ during the periods of 2006-2010 due to global economic crisis commenced in 2008.

Leesombatpiboon and Joutz (2010) investigated seven major economic sectors of Thailand economic including agriculture, construction, electricity, manufacturing, mining, residential and commercial, and transportation. They found that transportation used largest share as $38 \%$ of the total energy consumption. Meanwhile the second and the third major energy users are the industrial and residential and commercial sectors as about $32 \%$ and $24 \%$ of the total energy consumption respectively. Regarding to the petroleum products, transportation and agriculture are major consumption of high-speed diesel (HSD), while manufacturing and electricity sectors take the largest share equally $43 \%$ of total fuel oil consumption.

$\mathrm{Wu}$ et al. (2018) employed data development analysis to look at energy use, $\mathrm{CO}_{2}$ emission and economic-environmental efficiency performances in Asia-Pacific Economic Cooperation (APEC) for the period of 2006-2010. They found that Russia, Malaysia and Indonesia performance were worse compared to other countries. In terms of sectoral emitted to emission, they found that most 
of the $\mathrm{CO}_{2}$ emission in Russia, Malaysia and Indonesia derived by manufacturing industry of $37 \%$, $44 \%$ and $47 \%$ respectively.

Similar findings also find by Supasa et al. (2017). They studied using the consumption-based approach finds that the manufacturing, commercial, construction and road transport sectors were leading of $\mathrm{CO}_{2}$ emitters in Thailand. On the other hand, using production-based approach, they find that petroleum sources and power generation sectors are responsible for the nation emission. In addition, based on consumption with international trade and embodied emissions from imports and excluding those from exports, Thailand exhibit lower in $\mathrm{CO}_{2}$ emission for the years 2000 and 2010.

Particularly in Malaysia, Ong et al. (2012) claimed that transportations are the main contribution to $\mathrm{CO} 2$ emission because transportations are highly depending on petroleum products such as gasoline and diesels. Studied by Mustapa and Bekhet (2016) show out of the total CO2 emissions in transportation sector, road transportation account for the largest share with $85.2 \%$, followed by aviation, maritime and rail. Begum et al. (2015) indicated a huge proportion of $\mathrm{CO}_{2}$ emission comes from energy consumption of the power, industrial and transport sector. Similar findings also reported by Othman and Jafari (2013) where they show the primary key sectors that demonstrate the strong distributive and total effects were dominated by the energy industry and transportation sectors and were identified by calculating the emission elasticities that describe the relationship between $\mathrm{CO}_{2}$ emissions and the income generated in the country. In terms of economic expansion in relation to $\mathrm{CO} 2$ emission, Mustapa and Bekhet (2016) found that the $\mathrm{CO}_{2}$ emission in Malaysia increase in line with GDP growth. Shahbaz et al. (2013) also found similar result where economic growth has significant positive relationship with $\mathrm{CO}_{2}$ emission. A $1 \%$ rise in economic growth cause $0.7219 \%$ rise in $\mathrm{CO}_{2}$ emission.

\section{METHODOLOGY}

The Environmentally input output framework is employed in this study. This framework shows a complete picture of the economic system. It traces intersectoral relationship direct and indirect inputs used in the production process and can be used in environmental studies by linking economic and environmental variables on the production and consumption interventions (Hassan et al., 2014).

The Environmentally input output framework is suited to model the interlinkages between a range for environmental indicators and detailed structural economic information at the sector level for the analysis of energy policies. The proposed framework can be utilized as a tool for energy and environmental policy decisions which consider the impacts to resource consumption and environmental emissions.

We constructed an Environmentally Input-Output Table of Malaysia following the structure provided by Eora information by the (World Input-output Database, 2015). The individual country tables are available for download, and contain primary input, final demand blocks, imports and exports itemized by partner, and environmental satellite accounts for individual countries. Data are provided both Producers Prices (basic price) or Purchasers Price, and are in tab-delimited text files, which can be opened in Excel or any programming language. 
We decided to use all $\mathrm{CO}_{2}$ emissions from many types of energy use from all the sectors. In this model the country has been aggregated from 96 sector to a common 27 sector classification. The environmentally input-output table of Malaysia is following the structure provided by Eora IO table information, provided $\mathrm{CO}_{2}$ emissions from all the 27 sectors. The table is divided into the transaction's matrix T, primary inputs (also called value added), final demand, and satellite accounts $\mathrm{Q}$ for emissions associated with production and final consumers. The model for Malaysia is derived from the structure of the energy intensity of Malaysia environmentally input-output table.

Table 1: The structure of Malaysian environmentally input output table

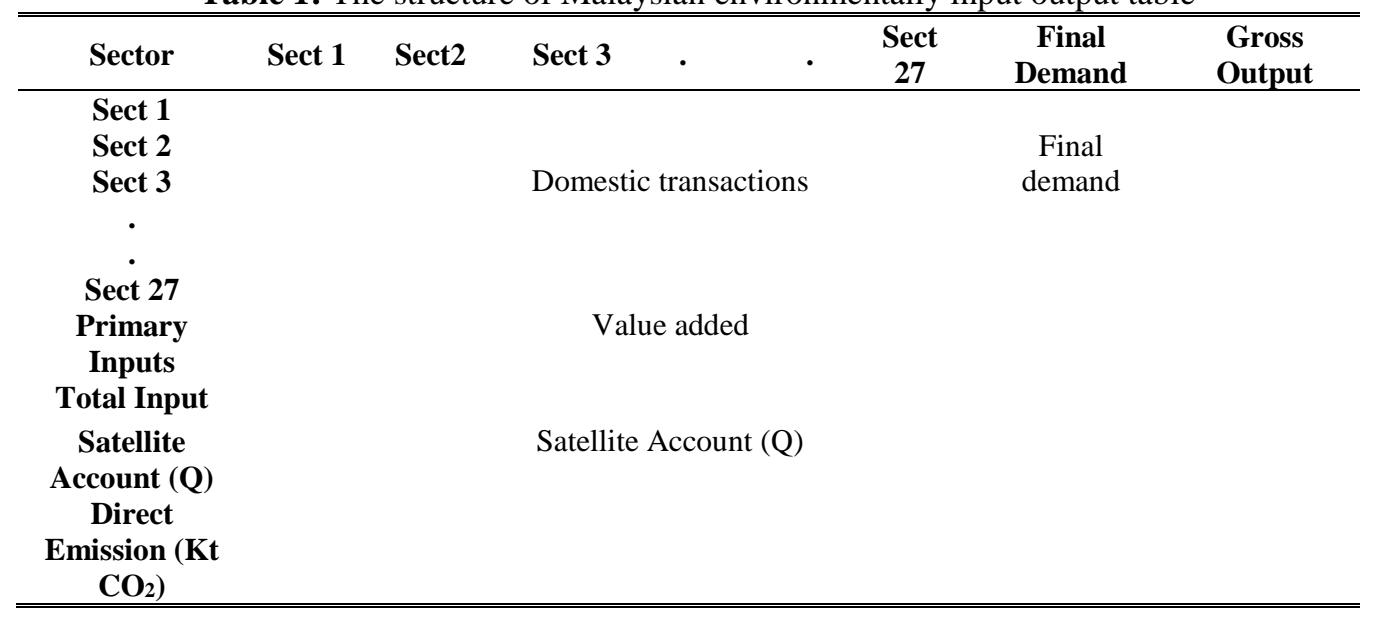

A Leontief price model has been implemented to investigate the potential impact of a $\mathrm{CO}_{2}$ taxation in the Malaysian economy (Harun et al., 2018). Based on Gemechu et al. (2014), the emission intensity Q:

$$
Q=e^{\prime}(I-A)^{-1}
$$

where vector $\mathrm{Q}$ in equation 1 is the $\mathrm{CO}_{2}$ intensity of each sector, e' is a row vector of sectoral emission in which each element $e_{i}$ represent the amount of $\mathrm{CO}_{2}$ emission produce a unit output of sector $\mathrm{j}$, A is n-by-n matrix of technical coefficients, whose element $a_{i j}$ measures the flow from sector $\mathrm{i}$ required to produce a unit output of industry $\mathrm{j}$ (Ying \& Harun, 2019).

\section{RESULTS}

The Carbon dioxide emission shows a large difference within 27 economic sectors in Malaysia as pictured in Figure 4. The high emissions were the result of Public administration with 89 million per metric ton carbon dioxide. This is associated with the huge use of energy by the Public administration. The other findings, for example in UK also shows the influenced of the amount of $\mathrm{CO}_{2}$ emission by public sector, and they are reducing their carbon emission by more than 17.5 million tonnes in the public sector since 2003 (Carbon Trust Organisation, 2017). Transportation 
is the second largest contributor to Carbon dioxide emission with 79 million per metric ton, results of burning fuel for cars, trains, and planes. Third highest emission sector was Electricity, gas and water which contributed 51 million per metric ton carbon dioxide. Meanwhile, the lowest emission sectors are represented in many services sectors such as Health and education, Real estate, Insurance, Hotel and restaurants and Wholesale and real estate.

Figure 4: Carbon Emission by Sectors

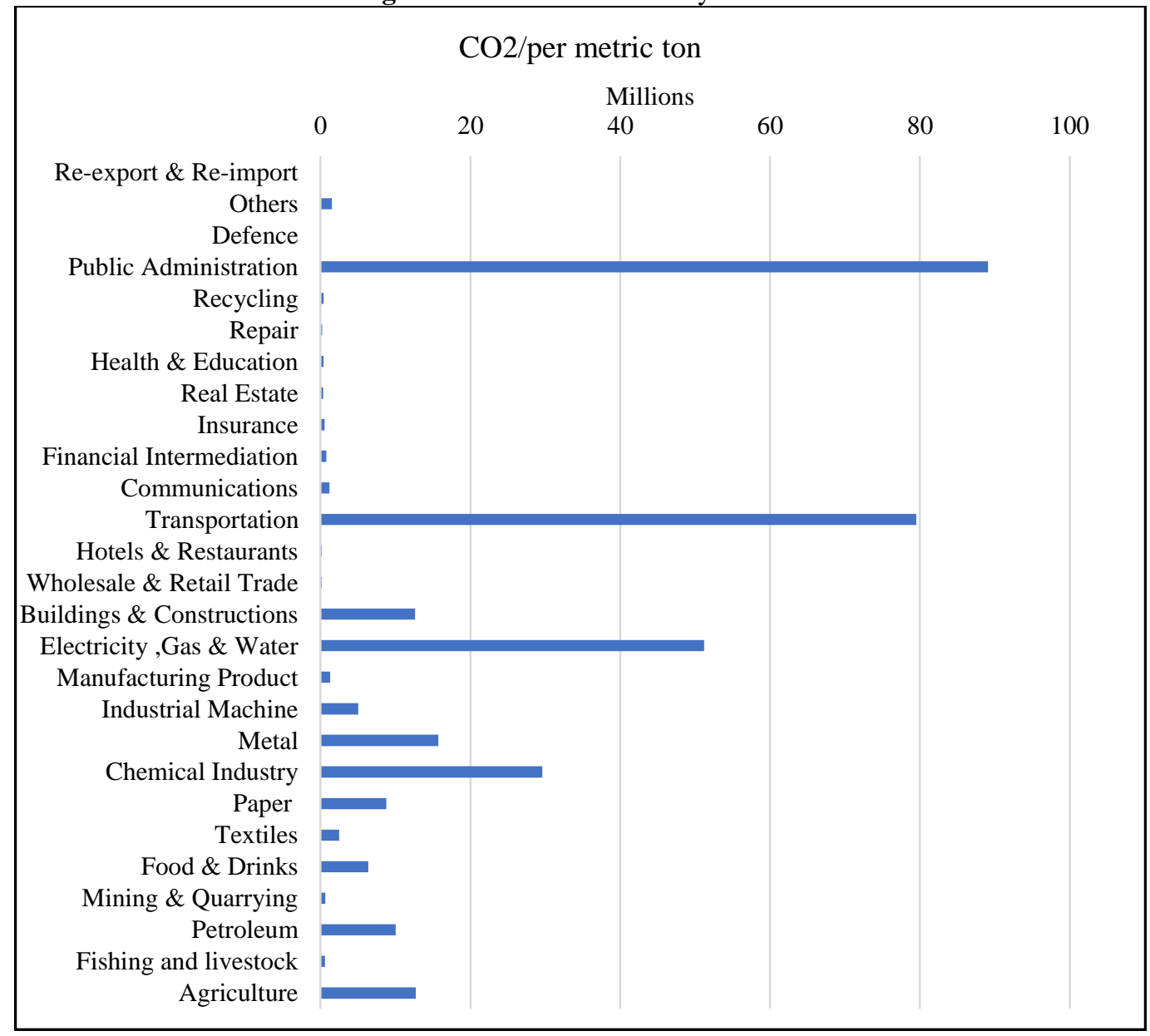

In term of $\mathrm{CO} 2$ energy intensities, there are also signficant differences in the $\mathrm{CO}_{2}$ emissions intensities within the 27 economic sectors as shown in Figure 5. According to a traditional definition, $\mathrm{CO}_{2}$ intensity measures the amount of $\mathrm{CO}_{2}$ emitted per unit of output (ton of $\mathrm{CO}_{2}$ per output-\$). However, this study that based on Gemechu et al. (2014) has broader definition of $\mathrm{CO}_{2}$ intensity, incorporating direct and indirect $\mathrm{CO}_{2}$ intensities. The amount of carbon emission produce by one sector is related to its productivity and technology efficiency. If a sector's carbon emission per ton is low comparing to its output, the $\mathrm{CO}_{2}$ emission intensity will be low representing high 
technology efficiency. Based on the Gemechu et al. (2014) calculation, the high emission intensity is levied on Building and construction sector, reflecting high consumption of energy in the production process for example cement, ceramic product in construction process. It could reflect the speed increase of the development level of economic expansion that forced the acceleration of the growth of the carbon emissions.

Next to Building and construction sector, Transportation, Electricity, gas and water, Chemical industry and Agriculture marks. Transportation high carbon emission intensity highlights the significant growth in the transportation development of railway, highway, water transport, and aviation, while high carbon emission intensity of Electricity, gas and water indicates its vital role in economic development. The Agriculture sector include production of oil palm, tea and rubber primary product which comprising a high energy demanding process, thus led to the high carbon emission intensities. In contrast, Insurance, Repair, Hotels and restaurants, Wholesale and retail trade, financial intermediation and Fishing and livestock have a low emission intensities level with respect to energy utilization.

Figure 5. The emission intensity by sector

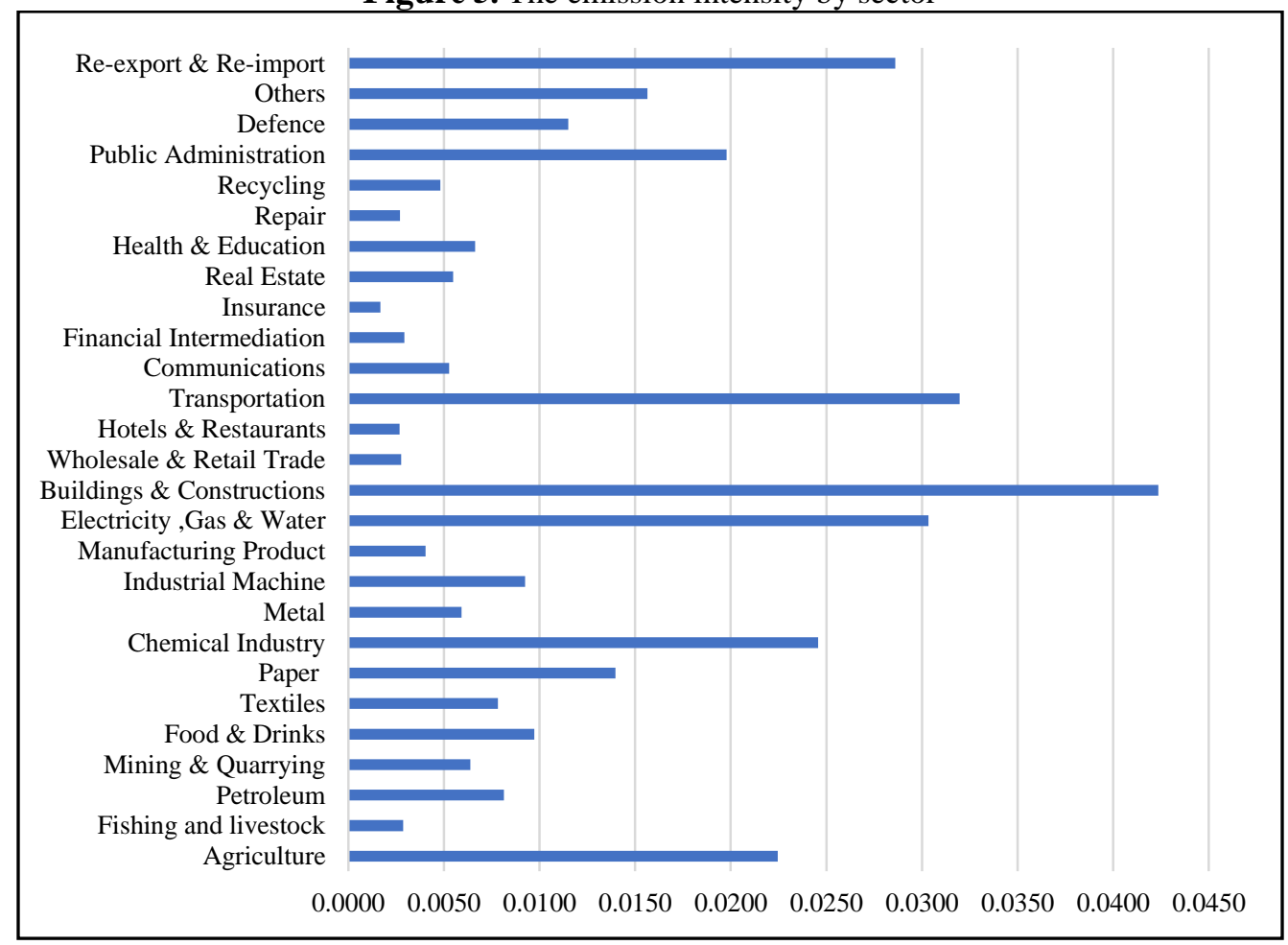

Sources: own calculation based on World input-output Database, World data Atlas Malaysia Environment. 


\section{CONCLUSION}

These results suggest that it is necessary to control environmental problems and encourage the energy use efficiency in the production process, particularly in the Building and construction sector, Transportation, Electricity, gas and water and Agriculture sector in Malaysia. Government should have a strategic plan and tools to manage $\mathrm{CO}_{2}$ emission with respect to climate change in these four sectors. It is also critical to identify the contributing factors of these sector carbon emissions intensities. In contrast to many other existing studies that found transportation sector as a main contributor to $\mathrm{CO}_{2}$ emission, we got different result where Transportation recorded the second highest contributor to $\mathrm{CO} 2$ emission.

Malaysia, as other developing country, must reduce carbon emissions because the country is one of the top $\mathrm{Co}_{2}$ emitting countries in the ASEAN region and depend heavily on fossil fuel in the development and promoting its economy. These findings suggest that it is necessary to control environmental problems, improving carbon emission efficiency and reducing carbon emissions in Malaysia. It is also critical to identify the contributing factors of these sector carbon emissions intensity. Thus, the major policy proposals these results suggest that policy makers should coordinate and promote the economic development and environmental resources.

The study recommends implementing a carbon tax that can be used to fund investment in alternatives energy, lead to further technological developments which has lower pollution costs. This environmental tax has been created in the developed world, particularly in the European Union (EU) since the ninety's century. The direct and indirect effects of $\mathrm{co}_{2}$ taxation in Malaysian could either be through a direct reduction in emissions that could be attained from the change in output induced by the tax, or through the use of parts of the revenues to stimulate cleaner technology.

\section{ACKNOWLEDGEMENT}

This research was supported by Ministry of Higher Education (MOHE) of Malaysia through Fundamental Research Grant Scheme (FRGS/1/2017/SS08/UUM/02/4).

\section{REFERENCES}

Begum, R. A., Sohag, K., Abdullah, S. M. S., \& Jaafar, M. (2015). CO2 emissions, energy consumption, economic and population growth in Malaysia. Renewable and Sustainable Energy Reviews, 41, 594-601.

British Petroleum Statistical Review of World Energy. (2014). London: British Petroleum. https://www.bp.com/content/dam/bp-country/de_de/PDFs/brochures/BP-statisticalreview-of-world-energy-2014-full-report.pdf

Carbon Trust Organisation. (2017). Public sector sustainability. https://www.carbontrust.com/

Gemechu, E. D., Butnar, I., Llop, M., \& Castells, F. (2014). Economic and environmental effects of CO2 taxation: an input-output analysis for Spain. Journal of Environmental Planning and Management, 57(5), 751-768. 
Harun, M., Mat, S. H. C., Fadzim, W. R., Khan, S. J. M., \& Noor, M. S. Z. (2018). The effects of fuel subsidy removal on input costs of productions: Leontief input-output price model. International Journal of Supply Chain Management, 7(5), 529-534.

Hassan, S., Othman, Z., \& Harun, M. (2014). Ownership structure variation and firm efficiency, Asian Social Science, 10(11), 233-241.

International Energy Agency. (2012) International Energy Outlook 2012: world petroleum and other liquid fuels. Energy Information Administration, Washington.

Jia, J., Gong, Z., Xie, D., Chen, J., \& Chen, C. (2018). Analysis of drivers and policy implications of carbon dioxide emissions of industrial energy consumption in an underdeveloped city: The case of Nanchang, China. Journal of Cleaner Production, 183, 843-857.

Leesombatpiboon, P., \& Joutz, F. L. (2010). Sectoral demand for petroleum in Thailand. Energy Economics, 32, 15-25.

Malaysian Energy Information Hub. (2017). Energy Commission of Malaysia. https://www.meih.st.gov.my/statistics/

Mustapa, S. I., \& Bekhet, H. A. (2016). Analysis of CO2 emissions reduction in the Malaysian transportation sector: An optimisation approach. Energy Policy, 89, 171-183.

Ong, H. C., Mahlia, T. M. I., \& Masjuki, H. H. (2012). A review on energy pattern and policy for transportation sector in Malaysia. Renewable and Sustainable Energy Reviews, 16(1), 532542.

Othman, J., \& Jafari, Y. (2013). Identification of the key sectors producing CO2 emissions in Malaysia: Application of input-output analysis (MPRA Paper No. 65192). Germany: University Library of Munich.

Supasa, T., Hsiau, S. S., Lin, S. M., Wongsapai, W., Chang, K. F., \& Wu, J. C. (2017). Sustainable energy and $\mathrm{CO} 2$ reduction policy in Thailand: An input-output approach from productionand consumption-based perspectives. Energy for Sustainable Development, 41, 36-48.

Mohd Safaai, N. S., Zainon Noor, Z., Hashim, H., Ujang, Z., \& Talib, J. (2011). Projection of CO2 emissions in Malaysia. Environmental Progress \& Sustainable Energy, 30(4), 658-665.

Shahbaz, M., Solarin, S. A., Mahmood, H., \& Arouri, M. (2013). Does financial development reduce $\mathrm{CO} 2$ emissions in Malaysian economy? A time series analysis. Economic Modelling, $35,145-152$.

World Bank. (2014). State and Trends Report Charts Global Growth of Carbon Pricing. https://www.worldbank.org/en/news/feature/2014/05/28/state-trends-report-tracks-globalgrowth-carbon-pricing

World Bank. (2018). States and Trends of Carbon Pricing 2018. https://openknowledge.worldbank.org/handle/10986/29687

World Input-Output Database. (2015). Eora National IO Table. Retrieved September 10, 2018 , from https://www.worldmrio.com/countrywise/

Wu, T. H., Chen, Y. S., Shang, W., \& Wu, J. T. (2018). Measuring energy use and CO2 emission performances for APEC economies. Journal of Cleaner Production, 183, 590-601.

Yildizhan, H. (2018). Energy, exergy utilization and CO2 emission of strawberry production in greenhouse and open field. Energy, 143, 417-423.

Ying, L. S., \& Harun, M. (2019). Fuel subsidy abolition and performance of the sectors in Malaysia: A computable general equilibrium approach, Malaysian Journal of Economic Studies, 56(2), 303-326. 